\title{
Dichrostachys cinerea Growth Rings as Natural Archives for Climatic Variation in Namibia
}

\author{
Benjamin Mapani, Rosemary Shikangalah, Isaac Mapaure, and \\ Aansbert Musimba
}

\section{Contents}

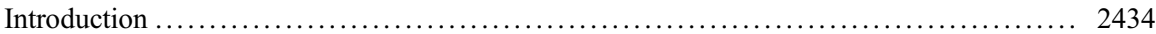

Evidence for Climatic Variation from Dendrochronological Studies .................. 2435

Samples and Data Processing ............................................. 2436

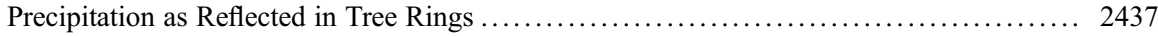

Growth Ring Responses to Climatic Variation .................................. 2439

Lessons Learnt from Arid and Semi-arid Savannas .............................. 2440

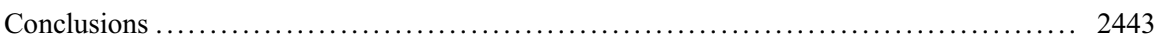

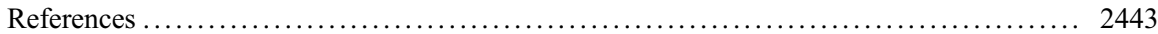

\section{Abstract}

Global Circulation Models (GCMs) are used to forecast climate change in Southern Africa, and the evidence shows that the region is going to warm up by up to $2^{\circ}$ by the year 2050. Namibia is one of the driest countries in Southern Africa and is at a high risk of becoming much drier than current situation by $57 \%$.

This chapter was previously published non-open access with exclusive rights reserved by the Publisher. It has been changed retrospectively to open access under a CC BY 4.0 license and the copyright holder is "The Author(s)". For further details, please see the license information at the end of the chapter.

\section{B. Mapani $(\bowtie)$}

Faculty of Engineering, Department of Mining and Process Engineering, Namibia University of Science and Technology, Windhoek, Namibia

R. Shikangalah

Faculty of Humanities and Social Sciences, Department of Geography, History and Environmental Studies, University of Namibia, Windhoek, Namibia

e-mail: rshikangalah@unam.na

I. Mapaure · A. Musimba

Faculty of Science, Department of Biological Sciences, University of Namibia, Windhoek, Namibia e-mail: imapaure@unam.na 
Very few studies have been carried out in Southern Africa to show actual impacts of climate change. Practical applicability of GCMs at a local spatial scale remains limited due to the coarse nature of the models. Hence, improvement of the GCMs must begin with better understanding of the local microclimates and how they respond to regional circulation patterns. In many regions of Southern Africa, the lack of potential tools to access old climatic records precludes the estimation of climate trends beyond 100 years. In spite of these impediments, there are areas with excellent tree species such as Dichrostachys cinerea that are able to be used as climatic archives for specific time periods. In this chapter, the study shows that the combination of tree ring chronologies and precipitation records is a powerful methodology in climate modeling in the southern hemisphere and reveals nuances that show climate change. The evaluation of data from tree rings coupled with precipitation trends reveals signals that show that climate has indeed been changing over the past ten decades and will have a negative impact on livelihoods. These data can now be used in predictive models that can be used to project future scenarios and assist policy makers and planners to see how climate will evolve in the next 50-60 years.

\section{Introduction}

Current scientific, observational, and anecdotal data show that climate change is now a well-observed phenomenon in most parts of the world (IPCC 2007, 2015; Shikangalah and Mapani 2019). Traditional livelihoods of subsistence farming, food security, water security, and cultural organizational patterns are likely to be, and some are already impacted by effects of Climate change. Thus, climate change will be a major problem in the near future, impacting water resources, agricultural and food systems in Southern Africa, particularly Namibia (Adhikari et al. 2015). In Namibia, there is an increasing trend observed in flooding, droughts, and evapotranspiration (Zeidler et al. 2010). The shortening of the crop growing season, rising average summer and winter temperatures, is among some of the evidence of climate change impacts in Namibia (Mapaure 2016). Temperature in Namibia has been increasing at three times the global mean, and the increase in temperature prediction for 2100 for Namibia ranges from $2{ }^{\circ} \mathrm{C}$ to $6^{\circ} \mathrm{C}$, particularly in the central regions (Reid et al. 2007).

These impacts will with time increasingly limit water supply, development activities, and consequently will affect all cross-sections of society (Ohlsson and Turton 1999; Showers 2002; Gumbo 2003; Wang et al. 2009). A number of authors have predicted that a quarter of the world's population will experience severe water scarcity within the first quarter of the next century and approximately a billion people in arid regions will face absolute water scarcity by 2025 (Seckler et al. 1999; Ruth et al. 2007). Water demand in urban areas is constantly on the upswing in Africa, Namibia, included (Mapani 2005; Shikangalah and Mapani 2019). The water demand is anticipated to rise by 50\% between 2010 and 2030 (Lafforgue 2016). 
Trees are excellent archives of environmental site conditions that affect their biological processes (Breitenmoser et al. 2014) and this information is reflected in their growth ring histories. Growth rings provide information about the history of the area in which the trees are resident, including other information such as tree age, fire events, droughts, attacks by pests, logging, and severe storms (Xing et al. 2012; Feliksik and Wilczyński 2009). Growth rings in trees are influenced by climate conditions and they show distinct episodes of moist and dry periods for over time (Novak et al. 2013; Palmer et al. 2018; Shikangalah et al. 2020). Dendrochronology can be used to reconstruct and draw conclusions about rainfall patterns over regional, hemispheric, or even global scales (Zhang 2015; NASA 2008). Tree growth rings are a valuable proxy for climate change studies on both local and regional scales (Nock et al. 2016; Novak et al. 2013; Steenkamp et al. 2008). Data from growth rings records is valuable for providing information that may not be available in areas where climate records never existed in the past. Hence, they aid the understanding of ecosystem dynamics and to predict changes in the ecological surroundings. This information is especially important in arid and semi-arid environments such as Namibia, where sound land management is crucial due to the climate-related vulnerability of such environments and the frequent lack of observational data. This holds particularly true for Namibia as the country is the most arid in Southern Africa and second only in aridity to the Sahara Desert in North Africa (Food and Agriculture Organization (FAO) 2005; Turpie et al. 2010). More than 90\% of Namibia's landmass is classified as semi-arid, arid, or hyper-arid, and the country is characterized by sporadic rainfall and high evaporation rates (Mendelsohn et al. 2002; Shanyengana et al. 2004; Barnard 2012). This chapter is aimed at assessing the responsiveness of $D$. cinerea to different climatic environments and thus be used as a proxy for climate change.

\section{Evidence for Climatic Variation from Dendrochronological Studies}

In this study, we selected sites that had a degree of variation in both precipitation and temperature. This climatic gradient revealed how the species responded to different amounts of rainfall and temperatures. The study sites are located at Lake Otjikoto $\left(19^{\circ} 11^{\prime} 41^{\prime \prime} \mathrm{S} ; 17^{\circ} 32^{\prime} 59^{\prime \prime} \mathrm{E}\right)$; Farm Onyoka located on the Waterberg Plateau Park $\left(20^{\circ} 25^{\prime} 0^{\prime \prime} \mathrm{S} ; 17^{\circ} 13^{\prime} 0^{\prime \prime} \mathrm{E}\right)$, and Farm Kuzikus $\left(23^{\circ} 20^{\prime} 0^{\prime \prime} \mathrm{S} ; 18^{\circ} 21^{\prime}\right.$ $59^{\prime \prime} \mathrm{E}$ ) located south of Windhoek (Fig. 1). The annual precipitation for the study sites is $550 \mathrm{~mm}$ to $600 \mathrm{~mm}$ for Lake Otjikoto, $450-500 \mathrm{~mm}$ for Onyoka, and less than $300 \mathrm{~mm}$ for Kuzikus. These sites also vary in temperature as follows: an average annual temperature of $25{ }^{\circ} \mathrm{C}$ for Lake Otjikoto, $30{ }^{\circ} \mathrm{C}$ for Waterberg Plateau Park, and $31{ }^{\circ} \mathrm{C}$ for Kuzikus (Mendelsohn et al. 2002). Lake Otjikoto has better soils of loamy to clay with a good water holding capacity as opposed to the deep sandy Kalahari soils (Kříbek et al. 2018; Mendelsohn et al. 2002; Rodgers et al. 2017). 


\section{Samples and Data Processing}

The precipitation data for 1970-2014 were obtained from Namibian official Meteorological Service in Windhoek. The growth rings of Dichrostachys cinerea were used, a native species to Namibia which is a fast-growing species that has become an undesirable encroacher and is particularly a problem in areas where there has been overgrazing (Orwa et al. 2009; Chepape et al. 2011; O’Connor et al. 2014). The population of $D$. cinerea decreases significantly from Lake Otjikoto site where the trees are abundant, to Kuzikus where the trees are very few (Fig. 1).

Wood samples of Dichrostachys cinerea were collected from randomly selected trees from three sites namely Lake Otjikoto, Waterberg, and Kuzikus (Fig. 1), with a total of 32 samples of $D$. cinerea. For each tree, one sample disc was taken at a height of about $1.0 \mathrm{~m}$ and air dried. The rings were identified using a combination of techniques for correction and validation of ring growth, that is, binocular microscope; WinDENDRO software, which automatically counts and dates each marginal parenchyma; and COFECHA program (Holmes 1983), which is commonly used in dendrochronology to ensure quality and measurement accuracy in growth ring segments

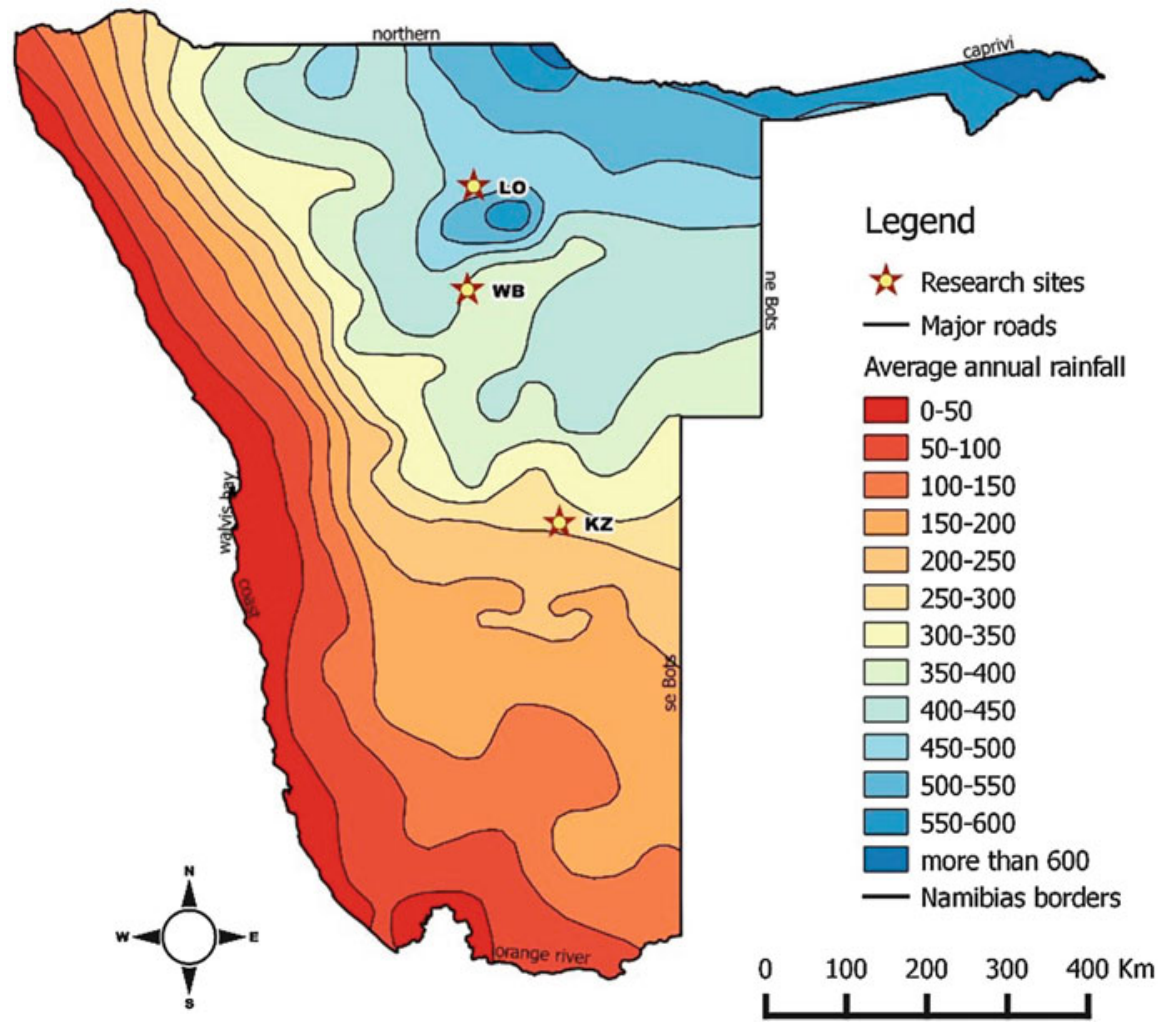

Fig. 1 The three study sites Lake Otjikoto (LO), Waterberg (WB), and Kuzikus (KZ) are shown along the rainfall gradient in Namibia 
(Grissino-Mayer 2001). To make sure that all the rings were correctly detected and dated by WinDENDRO software, at least four different paths radiating from the pith were created and analyzed (Grudd 2006; Heinrich et al. 2009; Shikangalah et al. 2020).

To explore the influence of temporal climatic variability on growth rings, the use of response and correlation functions from tree-ring chronologies and monthly climatic data was employed after the methods of Zang and Biondi (2013). Using the dplR package (Bunn 2008) of R 3.4.4 (R Core Team 2018), the $d c c$ function in TreeClim Package in $\mathrm{R}$ was used. The $d c c$ function builds upon and extends the functionality of program DENDROCLIM2002 (Biondi and Waikul 2004; Zang and Biondi 2013, 2015). A total of 32 samples were subject to spline detrending $(50 \%$ frequency) and then averaged to a chronology using Tukey's biweight robust mean. The timeframe used is only for the wet period (November of previous year-April of current year) is used between 1977 and 2015.

\section{Precipitation as Reflected in Tree Rings}

Rainfall in Namibia is unequally distributed, even in years when the country receives good rains, not all areas experience the same precipitation levels. Figure 2 shows the annual rainfall at the three study sites for the years 1970-2014. The rainfall distribution at the three sites follows the national trend where precipitation decreases from north-east to south west (Fig. 1). Figure 2 shows rainfall variability over four decades at the three study sites. At Lake Otjikoto, the annual rainfall was above the average $(558 \mathrm{~mm})$ for the years 1972-1974, 1976-1978, 1997, 2001, 2006, 2007-2008, and 2011-2012. At Waterberg, the following seasons had above average (471 mm) precipitation, 1973-1974, 1983-1984, 1987-1988, 2001-2001, and 2013-2014 seasons. Kuzikus has the least number of years with above average rainfall $(281 \mathrm{~mm})$, namely, 1973-1974, 1997, and 2006-2007. In decadal terms, the decade 1970-1979 had more rainfall than the 1980-1989 at Otjikoto, whereas the decade 1990-1999 had less rainfall than the 1970-1979 but higher rainfall than the

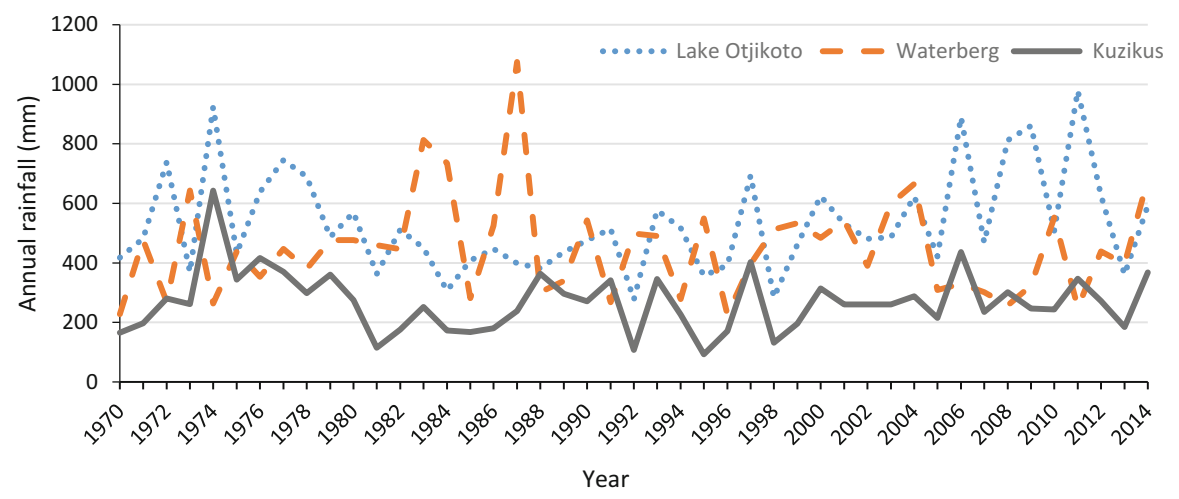

Fig. 2 Annual precipitation variation over the last four decades for Lake Otjikoto, Waterberg, and Kuzikus 
1980-1989 decade. However, the 1990-1999 decade at Otjikoto had a much higher variance than the previous two decades. This feature was much more enhanced in the 2000-2009 decade, where the variability was extreme. For Waterberg, the most variable decade in terms of precipitation was the 1980-1989 decade, followed by the 2000-2009. In the 2000-2009 decade, there was much less rainfall at Waterberg compared with the three previous decades. Kuzikus lies in a semi-arid zone, and precipitation variability is the norm. Kuzikus shows a highly variable precipitation signature over all the four decades.

In Fig. 3a, the growth of $D$. cinerea at Kuzikus (annual rainfall of $250-300 \mathrm{~mm} / \mathrm{a}$ ) shows a positive correlation with rainfall except in years when flooding occurred. At Waterberg (Fig. 3b) and Lake Otjikoto (Fig. 3c), the correlation is also positive. In

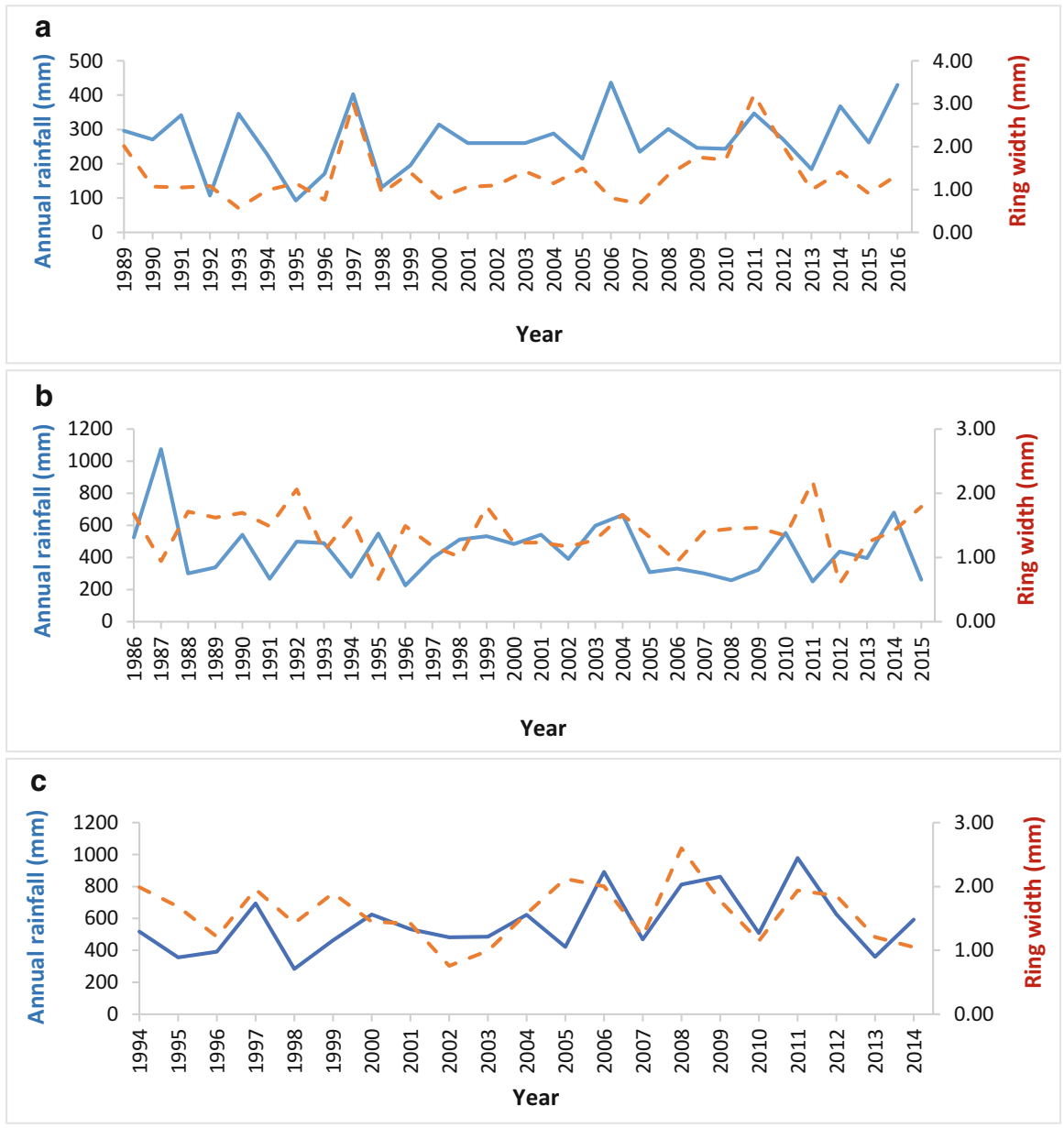

Fig. 3 The relationship between ring widths and annual rainfall Dichrostachys cinerea at (a) Kuzikus $(300 \mathrm{~mm}),(\mathbf{b})$ Waterberg $(450 \mathrm{~mm})$, and (c) Lake Otjikoto $(600 \mathrm{~mm})$, based on average growth ring of 4 trees per site 


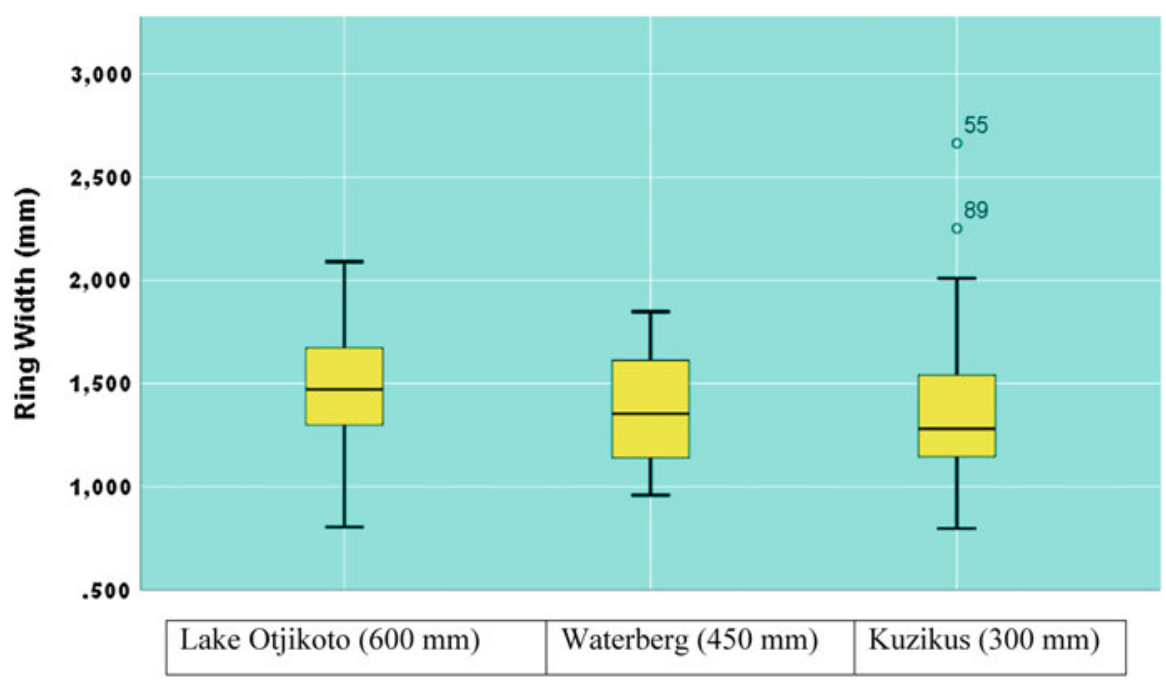

Fig. 4 Summary of all data from Fig. 3 for the three study sites. The median ring width for Otjikoto is much higher than for both Waterberg and Kuzikus

years when annual rainfall was received over a short period of time, resulting in runoff, the correlation is weak, for example, 2006 and 2016 at Kuzikus, and 1987 and 1995 at Waterberg. Figure 4 summarizes the comparisons in ring width growth across the precipitation gradient. Dichrostachys cinerea ring width growth correlates with the amount of precipitation, though the median ring widths did not significantly differ among sites.

\section{Growth Ring Responses to Climatic Variation}

Using bootstrapped correlation function analysis (R Core Team 2018), the darker bars in Fig. 5 indicate a coefficient significant at $p<0.05$, and the lines represent the $95 \%$ confidence interval. Figure 5 shows that the response coefficients of temperature, precipitation, and aridity at Lake Otjikoto and Kuzikus sites. The results shows that at Lake Otjikoto, the temperature, moisture availability, and overall aridity have positive but weak influence on growth rings in some months, mainly November and December (temperature), February (temperature and rainfall), and all three variables during March and April months (Fig. 5a). On contrary at Kuzikus, the influence of moisture availability is still positive but to a lesser extent than at Lake Otjikoto (Fig. $5 b)$. The temperature has a significant negative influence in growth rings in December (darker bar, Response Coefficients $(\mathrm{r})=-0.13$ ).

Figure 6 shows the autocorrelation lags of growth ring width with precipitation soil moisture. For Kuzikus, D. cinerea in the period 2000-2009 shows a negative correlation, whereas at Waterberg shows an intermediate response to precipitation soil moisture with growth ring width. The growth ring soil-moisture correlations at 


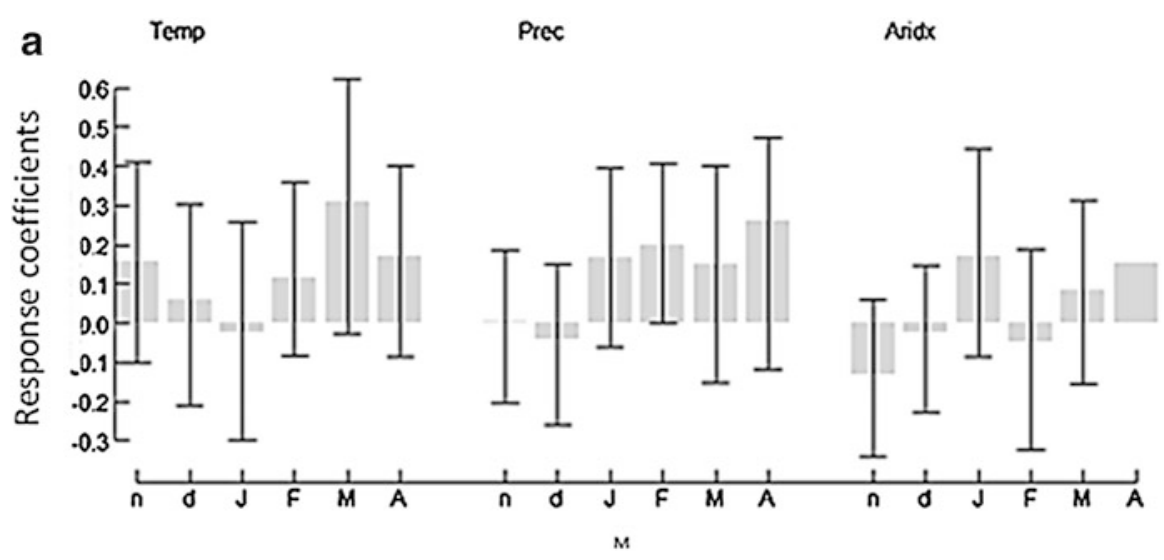

b $\quad$ Temp $\quad$ Prec $\quad$ Aridx

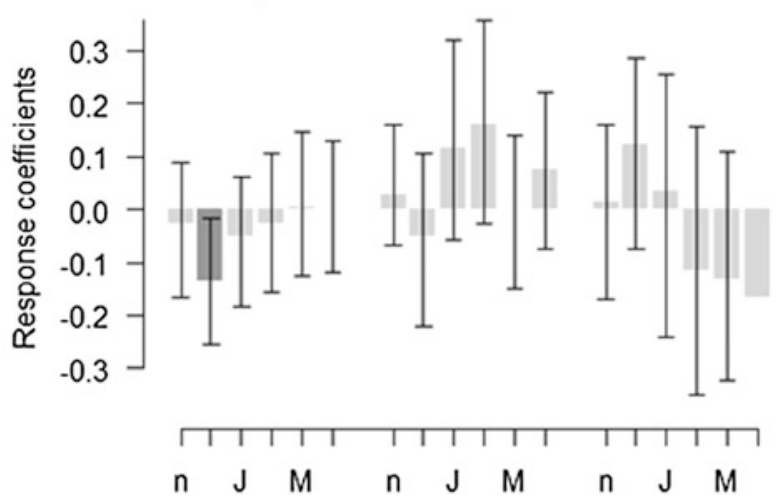

Fig. 5 (a) Lake Otjikoto site: $D$. cinerea growth ring responsiveness to temperature, precipitation, and aridity (climatic factors affecting tree growth the most). (b) Kuzikus site: $D$. cinerea growth ring responsiveness to temperature, precipitation, and aridity (climatic factors affecting tree growth the most)

Kuzikus where temperatures are high are much weaker compared to the correlations at Lake Otjikoto where rainfall is much higher. Lake Otjikoto shows a very strong positive correlation, way above the normality curve.

\section{Lessons Learnt from Arid and Semi-arid Savannas}

Evidence from precipitation (Fig. 2) and tree growth rings has shown that D. cinerea is sympathetic to precipitation soil moisture (Figs. 3, 4, and 5). This relationship is cardinal in the use of tree ring chronologies as proxies to climate variability. Trees are good archives of biomass systematic addition due to their physiological response to water stress that affects growth rings (McCarrol and Loader 2004). Additionally the stomatal conductance is controlled by the relative availability of edaphic 


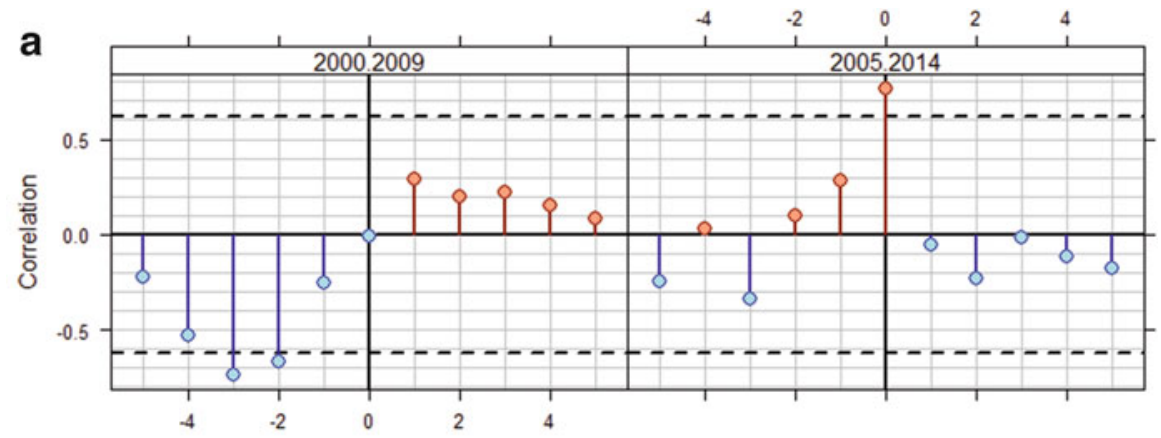

Lag

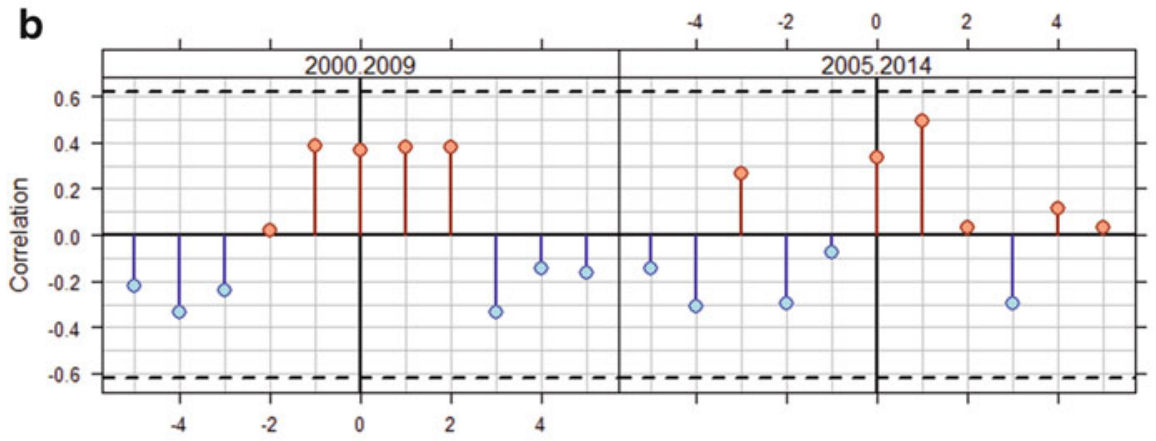

Lag

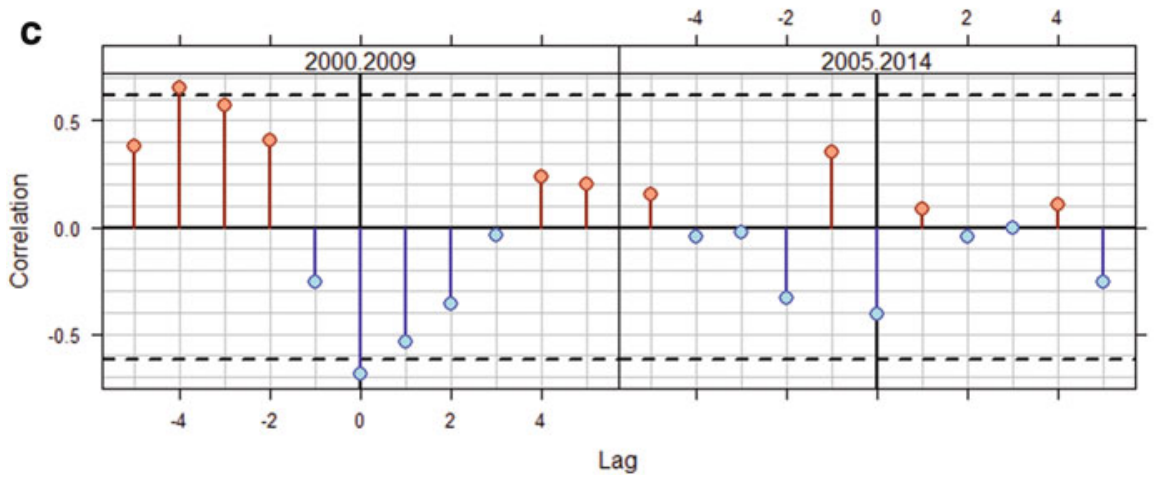

Fig. 6 Auto correlation lags (1-4) of rainfall with tree ring growth data. Kuzikus in (a) is a much drier and is the opposite of the wetter Otjikoto pattern in (c)

moisture (precipitation) and external leaf water vapor deficit (humidity) (Woodborne et al. 2015). In Namibia, the wet (rain) season used to start at the beginning of November four decades ago; and there has been a slow but gradual and systematic shift to mid-December in the past decade (Shikangalah and Mapani 2019). Such information is available in precipitation and tree ring growth records (Shikangalah et 
al. 2020). Work in Southern Africa has now proven beyond doubt that dendrochronology works as good as in the northern hemisphere for certain species of trees (Gourlay 1995; February 2000; Fichtler et al. 2004; Trouet et al. 2006; Woodborne et al. 2015; Shikangalah et al. 2020). Woodborne et al. (2015) reconstructed a 1000 year carbon isotope rainfall proxy record from the South African Adansonia digitata.

The key significance of soil moisture supply for the tree growth and its apparent influence is indicated in Fig. 4, where the Lake Otjikoto site with a higher mean annual precipitation shows a much higher ring width growth than at the other two sites. The data illustrate that $D$. cinerea growing in areas with high amounts of rainfall grows wider rings when all other climatic factors are taken together (Fig. 4). The patterns observed in rainfall (Fig. 2) are reflected in the autocorrelation diagrams (Fig. 6) which is a reflection of the microclimate effects on tree growth ring at each particular location. This suggests that $D$. cinerea growth rings can be used as a proxy for climatic variations wherever it is present. This finding is echoed by Kwak et al. (2016) who showed that soil moisture or groundwater near flowing streams influenced tree ring width growth and the size of the rings was proportional to the amount of moisture received.

The results show that in the years when floods occurred (Fig. 3), tree ring width did not correspond to the amount of rainfall received. This fact was attributed to runoff effects, where certain species do not add significant biomass under flooded conditions (e.g., Schulman 1945; Astrade and Bégin 1997; Kwak et al. 2016). Thus, there is an optimum maximum soil moisture threshold for $D$. cinerea.

Southern African species have been for a long time considered as not good at adding biomass systematically on an annual basis. However, tree chronologies for D. cinerea and S. mellifera were established by Shikangalah et al. (2020). Watkins et al. (2018) showed that tree ring sensitivity to climatic variables is dominated by precipitation. It is abundantly clear that for Southern Africa, Namibia, in particular, tree ring studies are excellent proxies for climate variability studies as they act as natural archives that record site conditions and precipitation effects.

The responsiveness of $D$. cinerea to precipitation, air temperature, and the overall aridity was also examined (Fig. 5). Overall, the response coefficients suggest contrast response of growth rings to climatic conditions at the two sites, with exception of rainfall and aridity in January and February. The low responses are mostly experienced at Kuzikus, while most of the positive responses are experienced at Lake Otjikoto. The response function also showed a precipitation response to a less significant correlation during February to April when the temperatures are cooler after some rainfall. The response coefficients are indicative periods on which the growth rings are quite small, suggesting that $D$. cinerea trees have a very narrow range of responsiveness in which they can grow, therefore supporting the evidence that they add the least amount of biomass in areas of less rainfall such as at Farm Kuzikus (Fig. 4). Due to the lack of darker bars which show a high significant response, these results demonstrate that growth rings are also influenced by other variables such as type of soil, groundwater, and vegetation. 


\section{Conclusions}

Growth rings in $D$. cinerea correlate to the amount of precipitation uptake by the species. Dichrostachys cinerea is dependent on rainfall for its survival, it has colonized wetter sites (Lake Otjikoto and Waterberg) more than it does in drier sites (e.g., Kuzikus). Therefore, it is much more important for farmers in high rainfall areas to anticipate more encroachment by $D$. cinerea and take necessary interventions to control or manage it. With regard to the usefulness of the species as proxy for modeling climatic conditions, it is concluded that $D$. cinerea is more responsive to climatic variables as it has proportionally responded to the amount of rainfall with ring growth and temperature. At Lake Otjikoto, growth rings are enhanced by both precipitation and temperature, whereas at Kuzikus, only the precipitation improves growth rings, the temperature effects the growth rings negatively. The findings from this chapter suggest that $D$. cinerea can be used as a proxy for precipitation shifts with time over relatively short periods, for instance, of 30- to 50-year histories, and where older trees can be found, it can be used to reconstruct climatic changes over several hundred years.

Acknowledgments The authors acknowledge the funding from the OPTIMASS project (01LL1302A), funded by the German Federal Ministry of Education and Research (BMBF). The authors also extend the assistance given by the Alfred Wagner Institute at Potsdam for using the laboratory facilities.

\section{References}

Adhikari U, Nejadhashemi AP, Woznick SA (2015) Climate change and eastern Africa: a review of impacts on major crops. Food Energy Secur 4:110-132

Astrade L, Bégin Y (1997) Tree-ring response of Populus tremula L. and Quercus robur L. to recent spring floods of the Saône River, France. Ecoscience 4:232-239

Barnard P (2012) Water and climate change, IBA Newsletter 2. Spring, p 3

Biondi F, Waikul K (2004) DENDROCLIM2002: a C++ program for statistical calibration of climate signals in tree-ring chronologies. Comput Geosci (UK) 30:303-311

Breitenmoser P, Brönnimann S, Frank D (2014) Forward modelling of tree-ring width and comparison with a global network of tree-ring chronologies. Clim Past 10:437-449

Bunn AG (2008) A dendrochronology program library in R (dplR). Dendrochronologia 26:115-124. https://doi.org/10.1016/j.dendro.2008.01.002

Chepape RM, Mbatha KR, Luseba D (2011) Local use and knowledge validation of fodder trees and shrubs browsed by livestock in Bushbuckridge area, South Africa. Livest Res Rural Dev 23:132. Available from: http://www.lrrd.org/lrrd23/6/chep23132.htm. Accessed 15 Aug 2018

February EC (2000) Archeological charcoal and dendrochronology to reconstruct past environments of Southern Africa. S Afr J Sci 96:111-116

Feliksik E, Wilczyński S (2009) The effect of climate on tree-ring chronologies of native and nonnative tree species growing under Homogenous site conditions. Geochronometria 33:49-57

Fichtler E, Trouet V, Beeckman H, Coppin P, Worbes M (2004) Climatic signals in tree rings of Burkea Africana and Pterocarpus angolensis from semiarid forests in Namibia. Trees 18 (4):442-451 
Food Agricultural Organisation (FAO) (2005) Namibia: irrigation in African in figures. Aquastat Survey. Retrieved from. http://www.fao.org/nr/water/aquastat/countries_regions/NAM/NAMCP_eng.pdf

Gourlay ID (1995) Growth ring characteristics of some African Acacia species. J Trop Ecol 11:121-140

Grissino-Mayer HD (2001) Evaluating crossdating accuracy: a manual and tutorial for the computer program COFECHA. Tree Ring Res 57:205-221

Grudd H (2006) Tree rings as sensitive proxies of past climate change. PhD dissertation. Stockholm University

Gumbo B (2003) The status of water demand management in selected cities of Southern Africa. In: WaterNet/Warfsa symposium: water, science, technology \& Policy convergence and action by all, vol. 7, pp 1-7. http://www.sciencedirect.com/science/article/pii/S1474706504001913

Heinrich I, Weidner K, Helle G, Vos H, Lindesay J, Banks JCG (2009) Inter-decadal modulation of the relationship between ENSO, IPO and precipitation: insights from tree rings in Australia. Clim Dyn 33(1):63-73

Holmes RL (1983) Computer-assisted quality control in tree-ring dating and measurement. TreeRing Bull 43:69-78

Intergovernmental Panel on Climate Change (IPCC) (2007) Climate change 2007: the physical science basis. Agenda 6(07):333. http://www.slvwd.com/agendas/Full/2007/06-07-07/Item\% 2010b.pdf

Intergovernmental Panel on Climate Change (IPCC) (2015) In: Pachauri RK, Meyer LA (eds) Climate change 2014 synthesis report. Contributing of Working Groups: I, II and III to the Fifth Assessment Report of the International Panel on Climate Change. IPCC, Geneva. 155pp. https:// doi.org/10.1017/CBO9781107415324

Kř́bek B, Sipkova A, Ettler V, Milhaljevic M, Majer V, Knésl I, Mapani B, Penizek V, Vanek A, Sracek O (2018) Variability of copper isotopic composition in soil and grass affected by mining and smelting in Tsumeb, Namibia. Chem Geol 493:121-135

Kwak J, Kim S, Kim G, Singh VP, Park J, Kim HS (2016) Bivariate drought analysis using streamflow reconstruction with tree rung indices in the Sacramento Basin, California, USA. Water 122. https://doi.org/10.3390/w8040122

Lafforgue M (2016) Supplying water to a water-stressed city: lessons from Windhoek. LaHouille Blanche 4:40-47. https://www.shf-lhb.org/articles/lhb/abs/2016/04/lhb2016038/lhb2016038. html

Mapani BS (2005) Groundwater and urbanisation, risks and mitigation: the case for the city of Windhoek, Namibia. Phys Chem Earth 30(11-16):706-711. https://doi.org/10.1016/j.pce.2005. 08.011. SPEC. ISS

Mapaure I (2016) Review of climate change in Namibia: projected trends, vulnerability and effects. In: Ruppel OC, Ruppel-Schlichting K (eds) Environmental law and policy in Namibia: towards making Africa the tree of life. Fully Revised and Updated Third Edition. Hanns Siedel Foundation, Windhoek, pp 339-358. ISBN 978-99945-79-88-4

McCarrol D, Loader NJ (2004) Stable isotopes in tree rings. Q Sci Rev 23(7):771-801

Mendelsohn J, Jarvis A, Roberts C, Robertson T (2002) Atlas of Namibia: a portrait of land and its people, vol 53. David Philip Publisher. https://doi.org/10.1017/CBO9781107415324.004

National Aeronautics and Space Administration (NASA) (2008) Global climate change and global warming: vital signs of the planet. Jet Propulsion Laboratory/National, CA, United States

Nock CA, Metcalfe DJ, Hietz P (2016) Examining the influence of site conditions and disturbance on rain forest structure through ring analyses in two Araucariaceae species. For Ecol Manag 366:65-72

Novak K, de Luis M, Raventos J, Cufar K (2013) Climatic signals in tree-ring widths and wood structure of Pinus halepensis in contrasted environmental conditions. Trees 27(4):927-936. https://doi.org/10.1007/s00468-013-0845-5

O'Connor TG, Puttick JR, Hoffman MT (2014) Bush encroachment in Southern Africa: changes and causes. Afr J Range Forage Sci 31:67-88. https://doi.org/10.2989/10220119.2014.939996 
Ohlsson L, Turton AR (1999) The turning of a screw: social resource scarcity as a bottle-neck in adaptation to water scarcity. Occasional paper series. School of Oriental and African Studies Water Study Group. University of London, London. https:/dlc.dlib.indiana.edu/dlc/bitstream/ handle/10535/5189/WF1-00 Social Resource Scarcity as a Bottle-Neck.pdf

Orwa C, Mutua A, Kindt R, Jamnadass R, Anthony S (2009) Agroforestry database: a tree reference and selection guide version 4.0. Available from: http://www.worldagroforestry.org/sites/treedbs/ treedatabases.asp. Accessed 14 Sep 2018

Palmer JG, Turney CSM, Fogwill C, Fenwick P, Thomas Z, Lipson M, Jones RT (2018) Growth response of an invasive alien species to climate variations on subantarctic Campbell Island. $\mathrm{N} \mathrm{Z}$ J Ecol 42(1):31-39. https://doi.org/10.20417/nzjecol.42.2

R Core Team (2018) R: a language and environment for statistical computing. Vienna, Austria, 0. Retrieved from https://www.r-project.org/

Reid HL, Stage J, MacGregor J (2007) The economic impact of climate change in namibia: economic program discussion paper 07-02. International Institute for Environmental and Development, London

Rodgers M, Bilton M, Hauptfleisch M (2017) Responses and feedbacks of burrowing mammals under differently managed rangelands. Namibian J Environ 1(A):40-51

Ruth M, Bernier C, Jollands N, Golubiewski N (2007) Adaptation of urban water supply infrastructure to impacts from climate and socioeconomic changes: the case of Hamilton, New Zealand. Water Resour Manag 21(6):1031-1045. https://doi.org/10.1007/s11269-006-9071-x

Schulman E (1945) Runoff histories in tree rings of the Pacific slope. Geogr Rev 35:59-73

Seckler D, Barker R, Amarasinghe U (1999) Water scarcity in the twenty-first century. Int J Water Resour Dev 15(1-2):29-42. https://doi.org/10.1080/07900629948916

Shanyengana ES, Seely MK, Sanderson RD (2004) Major-ion chemistry and groundwater salinization in ephemeral floodplains in some arid regions of Namibia. Namibian J Environ 57:71-83

Shikangalah RN, Mapani BS (2019) Precipitation variations and shifts over time: implication on Windhoek city water supply. Phys Chem Earth 112:103-112

Shikangalah R, Mapani BS, Mapaure I, Herzschuh U, Musimba A, Tabares X (2020) Growth ring formation of Dichrostachys cinerea and Senegalia mellifera in arid environments in Namibia. Dendrochronologia 59:125661

Showers KB (2002) Water scarcity and urban Africa: an overview of urban-rural water linkages. World Dev 30(4):621-648. https://doi.org/10.1016/S0305-750X(01)00132-2

Steenkamp CJ, Vogel JC, Fuls A, Van Rooyen N, Van Rooyen MW (2008) Age determination of Acacia erioloba trees in the Kalahari. J Arid Environ 72(4):302-313

Trouet V, Coppin P, Beeckman H (2006) Annual growth ring patterns in Branchystegia speciformis reveal influence of precipitation on tree growth. Biotropica 38(3):375-382

Turpie AJ, Midgley G, Brown C, Barnes J, Pallett J, Desmet P et al (2010) Climate change vulnerability and adaptation assessment for Namibia's biodiversity and protected. Ministry of Environment and Tourism, Directorate of Parks \& Wildlife Management, Windhoek

Wang Y, Xiao H, Wang R (2009) Water scarcity and water use in economic systems in Zhangye city, north olwestern China. Water Resour Manag 23(13):2655-2668. https://doi.org/10.1007/ s11269-009-9401-x

Watkins K, Patterson T, Knapp T (2018) Investigating the climatic sensitivity of Shortleaf Pine on a southeastern US College campus. Southeast Geogr 58(2):146-163

Woodborne S, Hall G, Robertson I, Patrut A, Rouault M, Loader NJ, Hofmeyr M (2015) A 1000year carbon isotope rainfall proxy record from South African Baobob trees (Adansonia digitata L.)

Xing P, Zhang Q, Baker PJ (2012) Age and radial growth pattern of four tree species in a subtropical forest of China. Trees 26:283-290

Zang C, Biondi F (2013) Dendroclimatic calibration in R: the bootRes package for response and correlation function analysis. Dendrochronologia 31(1):68-74

Zang C, Biondi F (2015) Treeclim: an R package for the numerical calibration of proxy-climate relationships. Ecography 38(4):431-436 
Zeidler J, Kandjinga L, David A (2010) Study on the effects of climate change in the Cuvelai Etosha Basin and possible adaptation measures. Integrated Environmental Consultants Namibia. A technical Report for the Cuvelai Basin

Zhang Z (2015) Tree-rings, a key ecological indicator of environment. Ecol Indic 51:107-116

Open Access This chapter is licensed under the terms of the Creative Commons Attribution 4.0 International License (http://creativecommons.org/licenses/by/4.0/), which permits use, sharing, adaptation, distribution and reproduction in any medium or format, as long as you give appropriate credit to the original author(s) and the source, provide a link to the Creative Commons license and indicate if changes were made.

The images or other third party material in this chapter are included in the chapter's Creative Commons license, unless indicated otherwise in a credit line to the material. If material is not included in the chapter's Creative Commons license and your intended use is not permitted by statutory regulation or exceeds the permitted use, you will need to obtain permission directly from the copyright holder.

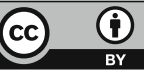

